Atmos. Chem. Phys., 10, 5281-5294, 2010

www.atmos-chem-phys.net/10/5281/2010/

doi:10.5194/acp-10-5281-2010

(C) Author(s) 2010. CC Attribution 3.0 License.

\title{
Measurements of volatile organic compounds over West Africa
}

\author{
J. G. Murphy ${ }^{1, *}$, D. E. Oram ${ }^{1}$, and C. E. Reeves ${ }^{1}$ \\ ${ }^{1}$ School of Environmental Sciences, University of East Anglia, Norwich, UK \\ * now at: Department of Chemistry, University of Toronto, Toronto, Canada \\ Received: 10 January 2010 - Published in Atmos. Chem. Phys. Discuss.: 10 February 2010 \\ Revised: 26 May 2010 - Accepted: 27 May 2010 - Published: 16 June 2010
}

\begin{abstract}
In this paper we describe measurements of volatile organic compounds (VOC) made using a Proton Transfer Reaction Mass Spectrometer (PTR-MS) aboard the UK Facility for Atmospheric Airborne Measurements during the African Monsoon Multidisciplinary Analyses (AMMA) campaign. Observations were made during approximately $85 \mathrm{~h}$ of flying time between 17 July and 17 August 2006, above an area between $4^{\circ} \mathrm{N}$ and $18^{\circ} \mathrm{N}$ and $3^{\circ} \mathrm{W}$ and $4^{\circ} \mathrm{E}$, encompassing ocean, mosaic forest, and the Sahel desert. High time resolution observations of counts at mass to charge $(\mathrm{m} / \mathrm{z}) \mathrm{ra}$ tios of 42, 59, 69, 71, and 79 were used to calculate mixing ratios of acetonitrile, acetone, isoprene, the sum of methyl vinyl ketone and methacrolein, and benzene respectively using laboratory-derived humidity-dependent calibration factors. Strong spatial associations between vegetation and isoprene and its oxidation products were observed in the boundary layer, consistent with biogenic emissions followed by rapid atmospheric oxidation. Acetonitrile, benzene, and acetone were all enhanced in airmasses which had been heavily influenced by biomass burning. Benzene and acetone were also elevated in airmasses with urban influence from cities such as Lagos, Cotonou, and Niamey. The observations provide evidence that both deep convection and mixing associated with fair-weather cumulus were responsible for vertical redistribution of VOC emitted from the surface. Profiles over the ocean showed a depletion of acetone in the marine boundary layer, but no significant decrease for acetonitrile.
\end{abstract}

Correspondence to: J. G. Murphy

(jmurphy@chem.utoronto.ca)

\section{Introduction}

Volatile organic compounds (VOC) is a term referring to a family of compounds that are emitted into the atmosphere from both natural and anthropogenic sources (primary) or produced in the atmosphere from chemical reactions (secondary). VOC play important roles in the production of two atmospheric pollutants, ozone and organic aerosol, that influence air quality and climate forcing. The tropics are a region with large potential for VOC emissions as a result of dense vegetation, significant biomass burning activities, and rapid population growth, including several mega-cities. Recent modelling studies have indicated that biogenic emissions are a dominant factor determining the regional ozone budget (Aghedo et al., 2007; Pfister et al., 2008; Saunois et al., 2009). The magnitude and distribution of biogenic emissions have been found to exert strong controls on the oxidative capacity of the tropical troposphere (Williams et al., 2009). Observations of low mass loadings of organic aerosol during the same flights described in this paper indicated that in this region, oxidation of biogenic VOC did not produce substantial amounts of secondary organic aerosol (Capes et al., 2009). The composition of the tropical troposphere is also significantly impacted by biomass burning (e.g. Crutzen and Andreae, 1990), and VOC such as acetonitrile can serve as tracers of biomass burning influence. This is particularly useful in West Africa, where observations of enhanced $\mathrm{O}_{3}$ and $\mathrm{CO}$ in the mid-troposphere during the wet season have been attributed to long range transport from fires across the equator (Sauvage et al., 2005; Thouret et al., 2009)

Published by Copernicus Publications on behalf of the European Geosciences Union. 
but back trajectories struggle to represent these transport patterns (Mari et al., 2008).

During the African Monsoon Multidisciplinary Analysis (AMMA) campaign, a suite of VOC was measured in situ using a Proton Transfer Reaction Mass Spectrometer (PTRMS) from the UK Facility for Atmospheric Airborne Measurements (FAAM). In this paper, we discuss measurements of the following group of VOC: acetone, acetonitrile, benzene, isoprene, and the sum of methyl vinyl ketone and methacrolein. A larger suite of VOC were quantified on the same flights at lower time resolution using canister sampling followed by post-flight analysis by GC-FID, as discussed in Hopkins et al. (2003, 2009). Two French aircraft participating in AMMA also collected VOC using multisorbent tubes with post-campaign analysis by GC-MS (Bechara et al., 2008). VOC measurements were made at a ground-based forested site in Benin in June of 2006 with a focus on the biogenic compounds isoprene and monoterpenes (Saxton et al., 2007).

The species measured by PTR-MS during AMMA include both primary and secondary VOC with a wide range of sources and lifetimes. In many cases, the main sink of the VOC is oxidation by the hydroxyl radical; for the sake of illustration we calculate a lifetime using the appropriate rate constant at $298 \mathrm{~K}$ (Atkinson et al., 2006) and an average $[\mathrm{OH}]$ of $1 \times 10^{6} \mathrm{molec} \mathrm{cm}^{-3}$. This estimate for average $[\mathrm{OH}]$ is consistent with the slightly higher range of daytime $[\mathrm{OH}]$ measured during flights on FAAM (Commane et al., 2010). Benzene is predominantly emitted during fossil fuel combustion and biomass burning and it has a lifetime of 10 days against oxidation by $\mathrm{OH}$. It is believed that biomass burning is the main source of acetonitrile to the atmosphere (de Gouw et al., 2003c), while estimates of its atmospheric lifetime range from $\sim 1$ year against oxidation by $\mathrm{OH}$, to months if ocean uptake is assumed to be significant (de Gouw et al., 2003c; Sanhueza et al., 2004; Singh et al., 2003). The global atmospheric budget of acetone, reviewed in Jacob et al. (2002), includes primary sources from anthropogenic and biogenic emissions and a photochemical ocean source, in addition to secondary production from oxidation of anthropogenic and biogenic VOC. Photolysis, oxidation by $\mathrm{OH}$, and dry deposition were all identified as important sinks, resulting in an average lifetime on the order of two weeks. In contrast to these relatively long-lived gases, isoprene has a lifetime against oxidation of approximately two hours. Its main source is emission from terrestrial vegetation, the rate of which depends on plant type and environmental variables (Guenther et al., 2006). Methyl vinyl ketone and methacrolein are oxygenated VOC that are produced from the oxidation of isoprene and can themselves be lost to $\mathrm{OH}$ on a timescale of several hours. As a result of the shorter lifetimes of the biogenic compounds, their geophysical distributions tend to be linked more closely to emission sources.

In Sect. 2 of this paper, we describe experimental details, including the context of the AMMA campaign and the operation of the PTR-MS instrument. An overview of the observations and their geophysical distributions are presented in Sect. 3, while in Sect. 4 we focus on individual case studies that serve as examples of some of the processes governing the vertical distribution of VOC in the troposphere over West Africa. A summary and conclusions are presented in Sect. 5.

\section{Experimental}

\subsection{African Monsoon Multidisciplinary Analyses (AMMA)}

The African Monsoon Multidisciplinary Analysis (AMMA) is an international project designed to improve our knowledge and understanding of the West African monsoon (WAM) and its variability with an emphasis on daily-tointerannual timescales. The flights described took place during a Special Observing Period (SOP2) designed to coincide with the maximum in the West African Monsoon in the summer of 2006 (Reeves and al., 2010). The UK FAAM aircraft was stationed in Niamey, Niger, and flew nearly 100 hours over Benin, Burkina Faso, Ghana, Mali, Niger, Nigeria, and Togo. VOC observations are available for $85 \mathrm{~h}$ between 17 July and 17 August 2006, in an area between $4^{\circ} \mathrm{N}$ and $18^{\circ} \mathrm{N}$ and $3^{\circ} \mathrm{W}$ and $4^{\circ} \mathrm{E}$, encompassing ocean, mosaic forest, and the Sahel desert. In this region, meridional variability dominates the zonal variability in land surface type and atmospheric composition, with sharp transitions between ocean and forest and forest and desert occurring around $6^{\circ} \mathrm{N}$ and $12^{\circ} \mathrm{N}$, respectively (Janicot et al., 2008). The FAAM BAe-146 flew mainly in the boundary layer and lower free troposphere, and VOC observations are available between $150 \mathrm{~m}$ above ground up to $9500 \mathrm{~m}$.

\subsection{Proton Transfer Reaction Mass Spectrometry (PTR-MS)}

Measurements of a suite of volatile organic compounds were made by proton transfer reaction mass spectrometry (PTRMS) with adaptations to the original instrument from Ionicon Analytik (Lindinger et al., 1998). A pressure-controlled inlet allowed us to maintain a constant pressure (between 2.2 and $2.4 \mathrm{mbar}$ ) in the drift tube while making measurements up to an altitude of $9500 \mathrm{~m}$. The drift tube field strength $(\mathrm{E} / \mathrm{N})$ used for the observations was $105 \mathrm{Td}$ and the temperature was controlled at $313 \mathrm{~K}$. Because of the quadrupole mass filter, specific masses corresponding to protonated species of interest were measured for one second every 10-20 s. The PTR-MS drew air from a forward-facing starboard air sampling pipe shared by the $\mathrm{O}_{3}$ and $\mathrm{NO}_{\mathrm{x}}$ instruments. Zeros were carried out periodically in-flight by diverting the sample air stream for a period of 1-2 min through a custom-built stainless steel tube filled with a platinum-coated quartz wool catalyst (Shimadzu) continuously heated to $400^{\circ} \mathrm{C}$. For the 
species discussed in this paper, there was very little variability between zeros through time or as a function of altitude. The response of the PTR-MS was calibrated pre- and postcampaign using a multi-component standard (Apel-Riemer) with individual compounds certified to have an accuracy of 5\%. Due to the high absolute humidity encountered during the flights, the protonation of VOC by both $\mathrm{H}_{3} \mathrm{O}^{+}$and the water cluster, $\mathrm{H}_{3} \mathrm{O}^{+} \mathrm{H}_{2} \mathrm{O}$, was taken into account, following the convention of de Gouw et al. (2003b). In this formulation, the ion signal for each VOC is normalized to the two dominant reagent ions:

Normalized ion signal

$=10^{6} \frac{i\left[\mathrm{VOC}-\mathrm{H}^{+}\right]}{i\left[\mathrm{H}_{3} \mathrm{O}^{+}\right]+X_{\mathrm{r}} \times i\left[\mathrm{H}_{3} \mathrm{O}^{+} \mathrm{H}_{2} \mathrm{O}\right]}$

where $i\left[\right.$ VOC- $\left.\mathrm{H}^{+}\right], i\left[\mathrm{H}_{3} \mathrm{O}^{+}\right]$, and $i\left[\mathrm{H}_{3} \mathrm{O}^{+} \mathrm{H}_{2} \mathrm{O}\right]$ are the ion signals of the product and reagent ions, and $X_{\mathrm{r}}$ is compound specific and was determined empirically by performing variable humidity calibrations in the laboratory. During AMMA the average value of $i\left[\mathrm{H}_{3} \mathrm{O}^{+}\right]$was $6 \times 10^{6}$ counts per second, and $i\left[\mathrm{H}_{3} \mathrm{O}^{+} \mathrm{H}_{2} \mathrm{O}\right]$ varied strongly as a function of absolute humidity ranging from $2 \times 10^{5}$ and $3 \times 10^{6} \mathrm{cps}$. The laboratory humidity calibrations covered the same range of $i\left[\mathrm{H}_{3} \mathrm{O}^{+} \mathrm{H}_{2} \mathrm{O}\right]$ that was encountered during the flights. For the compounds discussed in this paper, the $X_{\mathrm{r}}$ values were 0.71 for acetonitrile, 0.09 for benzene, 0.68 for acetone, 0.85 for isoprene, and 0.79 for MVK+MACR.

Acetonitrile is assumed to be the dominant species contributing to the signal at $m / z=42$. The possible contribution from $\mathrm{O}_{2}^{+}+$alkane reactions, is expected to be negligible especially as a result of the high humidity conditions, which suppressed $\mathrm{O}_{2}^{+}$in the drift reactor. In many studies, benzene has been shown to be the only molecule contributing to the signal at $m / z=79$ (e.g. Warneke et al., 2003), and possible contributions from ethyl benzene should be negligible at the relatively low electric field strength used in our system (de Gouw et al., 2003a). Acetone is considered to be the dominant contributor at $m / z=59$. While propanal can also contribute at this $\mathrm{m} / \mathrm{z}$, its contribution relative to acetone in urban air is minimal (Warneke et al., 2003), and is expected to diminish further downwind from sources (de Gouw et al., 2003b). Glyoxal is a short-lived dicarbonyl compound formed largely from oxidation of parent VOC that could also interfere at $m / z=59$. Recent satellite observations indicate that the column density in this region and season is approximately $5 \times 10^{14} \mathrm{molec}^{-2}$ (Stavrakou et al., 2009). To give an upper estimate for a mixing ratio, if one assumes this resides entirely in a $1 \mathrm{~km}$ deep mixed layer at the surface, this results in a mixing ratio of $\sim 200 \mathrm{ppt}$, in the same range as in situ measurements compiled in Vrekoussis et al. (2009). While we cannot rule out the possibility that this compound makes a contribution at $m / z=59$, it is likely minor compared to the significant amounts of acetone.

Isoprene is assumed to be the major contribution to the signal at $m / z=69$. While isobaric interferences have been noted in other environments, for example the dehydration product of methyl butenol, excellent agreement was observed between PTR-MS observations and whole air samples analyzed post-flight by GC-MS $\left(R^{2}=0.84\right.$, slope $=0.95 \pm 0.05$, intercept $=-10 \pm 32 \mathrm{ppt})$, indicating that isoprene was the dominant compound at $m / z=69$ (Murphy et al., 2006). Both methyl vinyl ketone (MVK) and methacrolein (MACR) contribute to the signal at $\mathrm{m} 71$, thus only the sum of their mixing ratios can be reported. Individual permeation tubes (Ecoscientific) were used to measure their independent responses, which showed them to be within $20 \%$ of each other, and the average was used in the analysis. A conservative estimate of the total uncertainty of the reported sum (MVK+MACR) is $\pm 27 \%$, for the unlikely scenario in which only one of the compounds contributes at this mass. Assuming the identified compounds are solely responsible for the signals at the $\mathrm{m} / \mathrm{z}$ selected, the accuracy for acetonitrile, acetone, isoprene and benzene, are estimated to be $\pm 15 \%$, accounting for uncertainties in flows and humidity-dependent calibration factors. Because the background signals varied between flights, and the reagent ion abundance varied during each flight, the detection limits for each species are not constant. The range of detection limits calculated for $1 \mathrm{~s}$ measurements of each species for each flight are shown as grey bars below the $\mathrm{x}$ axis in Fig. 1.

Other studies have used observations at $m / z=33,45$, and 93 to calculate the mixing ratios of methanol, acetaldehyde, and toluene respectively. While we monitored these signals during the flights, we are not able to provide quantitative data for the mixing ratios of these compounds. In the case of methanol, the sampling and zeros had a strong altitude dependence, which could not be corrected for, even after accounting for the strong humidity dependence (because water depletes $\mathrm{O}_{2}^{+}$, and ${ }^{17} \mathrm{O}^{16} \mathrm{O}$ has an isobaric interference at $m / z=33$ ). It is possible that additional humidity-dependent corrections are required that could not be accounted for in our post-processing data treatment. The behaviour of $m / z=45$ appeared reasonable during ambient sampling, but the signal when the air was diverted through the heated catalyst was often higher than ambient air. This suggests that either acetaldehyde, or something else at $m / z=45$, was generated in our heated catalyst, and may also indicate interferences during normal sampling, which have been noted in the past (Northway et al., 2004). The system had a high background at $m / z=93$, and ambient mixing ratios of toluene rarely exceeded the detection limit of 200 ppt.

Monoterpenes have been detected using the parent mass at $m / z=137$ or a fragment at $m / z=81$ (Lee et al., 2005), but neither approach was successful here. Extremely high signals were noted during zeros that occurred in the boundary layer at $m / z=81$, but not at $m / z=137$. Post-flight calibrations using $\alpha$-pinene indicated a low sensitivity to monoterpenes in our system at $m / z=137$, and the most quantitative information we can provide is that monoterpenes rarely exceeded the detection limit at this mass, which was in the range of $500 \mathrm{ppt}$. 

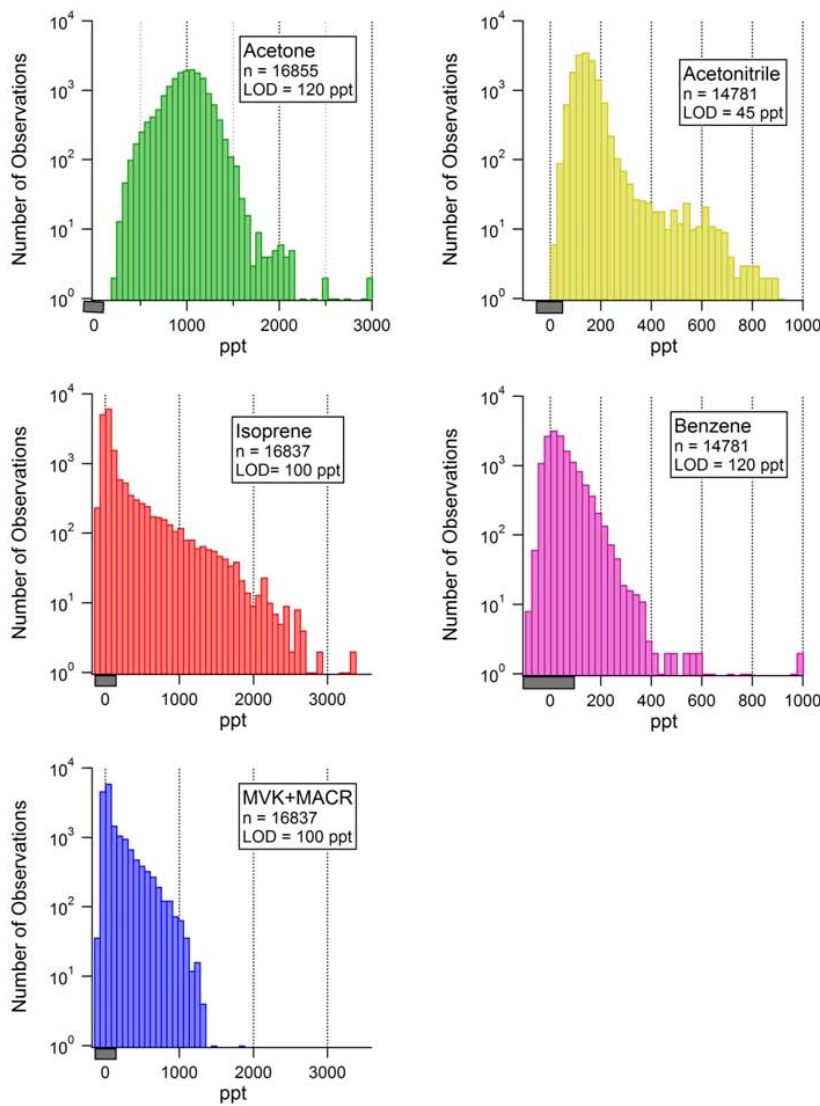

Fig. 1. Histograms of the distribution of observations of acetone, acetonitrile, isoprene, benzene, and the sum of methyl vinyl ketone and methacrolein. The total number of points in each histogram is given in the legend, along with a conservative estimate of the $3 \sigma$ limit of detection for $1 \mathrm{~s}$ measurements, which is also indicated visually using a grey bar along the $\mathrm{x}$-axis.

While ground-based measurements in the region showed evidence of large emissions of monoterpenes from some plant species (Saxton et al., 2007), samples collected on the aircraft and subsequently analyzed by gas chromatography coupled to time-of-flight mass spectrometry (GC-TOFMS) contained low amounts of four individual monoterpenes (Capes et al., 2009), consistent with PTR-MS results.

\subsection{Supporting measurements}

Other observations from FAAM used in this analysis include mixing ratios of $\mathrm{O}_{3}, \mathrm{NO}_{\mathrm{x}}, \mathrm{CO}$, from the core chemistry rack. The instruments used are TECO $49 \mathrm{UV}$ photometer for $\mathrm{O}_{3}$, the TECO 42 chemiluminescence instrument for $\mathrm{NO}_{\mathrm{x}}$, and the Aerolaser AL5002 for CO, which all used a common air sample inlet pipe. The altitude, latitude, and longitude reported in the paper were all measured using the Navstar Global Positioning System at $1 \mathrm{~Hz}$. Liquid water content was measured using a Johnson Williams Liquid Water Content probe at $4 \mathrm{~Hz}$. All data were averaged to the duration of a single cycle of measurements on the PTR-MS, which ranged from 10-20 s for different flights, depending on the number of compounds measured. The exception is the first three flights, when the system had not yet been optimized and data were averaged to one minute to improve the signal to noise.

\section{Observations}

In Fig. 1 we present histograms of the VOC successfully measured by PTR-MS from FAAM during AMMA. A grey bar below the $\mathrm{x}$-axis is used to denote the range of mixing ratios within the $3 \sigma$ detection limit calculated for $1 \mathrm{~s}$ measurements of each VOC. For benzene, isoprene, and the sum of methyl vinyl ketone and methacrolein, at least half of the observations were below the detection limits for these compounds during the campaign. On the other hand, measurements of acetonitrile and acetone nearly always exceeded the detection limits. In $85 \mathrm{~h}$ of flying time, we sampled air throughout the troposphere including the boundary layer over the ocean, the mosaic forest and the Sahel desert. Though the flights often targeted certain areas and phenomena, the data offer representative constraints on the range of concentrations encountered in the region as a whole during the monsoon season.

More information about the processes governing the abundance of these compounds can be obtained from Fig. 2, which depicts the geophysical distribution of the compounds. Sources of acetone include primary emissions and secondary production from the oxidation of other VOC. As a result, its geophysical distribution can be difficult to interpret. The highest mixing ratios were observed in airmasses with urban or biomass burning impact, while the lowest were observed in low level runs in the marine boundary layer over the Gulf of Guinea. In general, acetone decreased at altitudes above $4000 \mathrm{~m}$, except when the aircraft sampled air that had been recently lofted from the surface by strong convective systems. Acetonitrile mixing ratios were relatively constant, in the range of 100-150 ppt, with the exception of strong enhancements in biomass burning outflow. Benzene was also enhanced in biomass burning plumes, but the highest concentrations were seen in urban-influenced air. In general, mixing ratios of benzene were below the detection limit above $4000 \mathrm{~m}$. Isoprene mixing ratios were below the detection limit, except in lowest $\sim 1500 \mathrm{~m}$ over the forest surface between 6 and $12^{\circ} \mathrm{N}$, where they showed a strong correspondence to surface vegetation (Ferreira et al., 2010). The sum of isoprene oxidation products, methyl vinyl ketone and methacrolein (MVK+MACR) were high in the same region as isoprene but also slightly further north (downwind in the monsoon flow). Their mixing ratios were also enhanced up to $4000 \mathrm{~m}$ above the vegetated surface, consistent with the lifetimes being significantly longer than isoprene. 

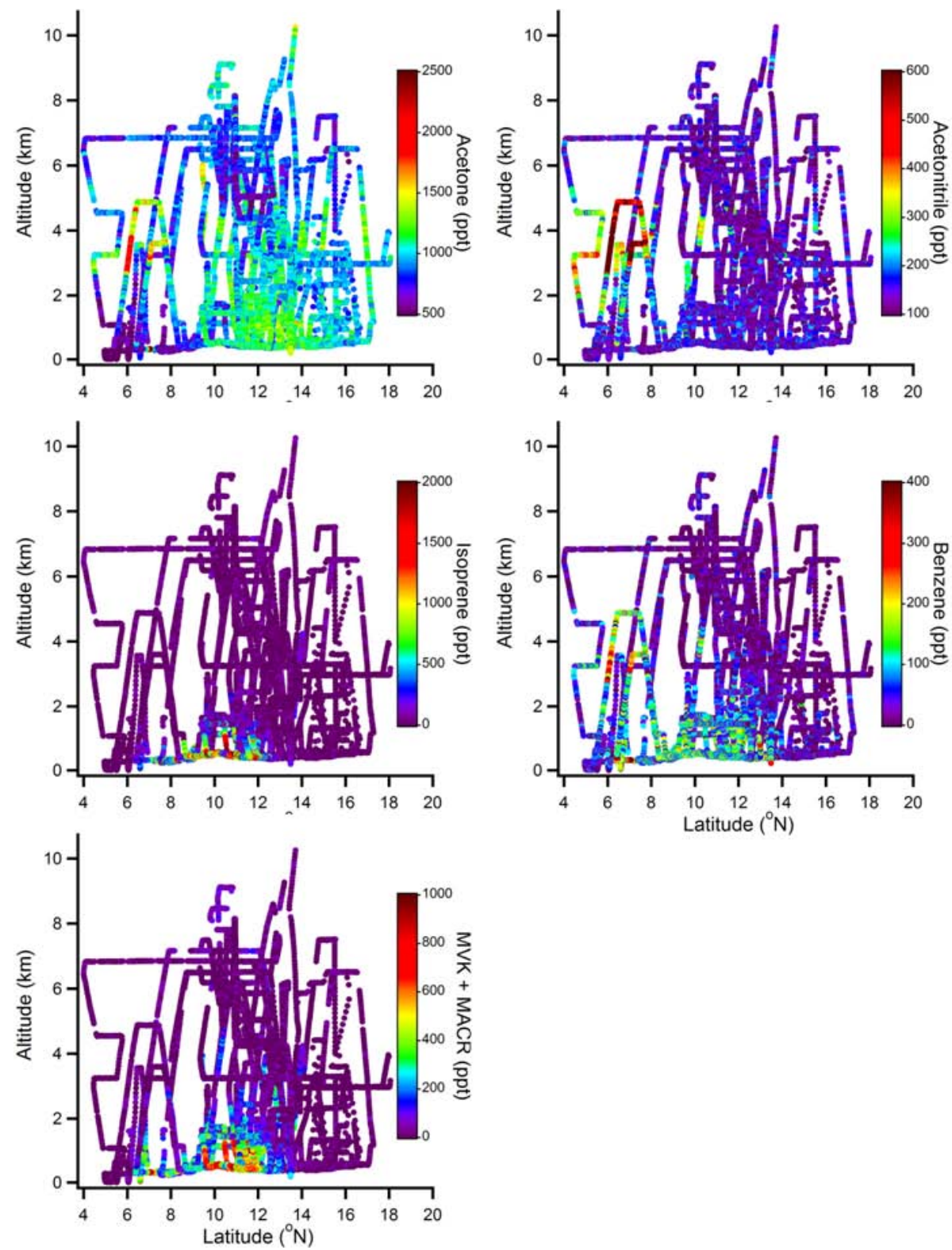

Fig. 2. Geophysical distributions of VOC in West Africa, with individual observations plotted according to altitude on the y-axis, latitude on the $\mathrm{x}$-axis and coloured by mixing ratio. Transitions occur at the coast of the Gulf of Guinea $\left(6^{\circ} \mathrm{N}\right)$ and between the forest and Sahel $\left(12^{\circ}-13^{\circ} \mathrm{N}\right)$. Airports in Cotonou, Lagos, and Niamey are at $6.3^{\circ}, 6.6^{\circ}$, and $13.5^{\circ} \mathrm{N}$, respectively.

Table 1 provides the average and standard deviations of the mixing ratios of each of the VOC, and additionally $\mathrm{CO}$ and $\mathrm{O}_{3}$, in surface air over different surface types. For this analysis, we have considered surface air to be anything below a GPS altitude of $700 \mathrm{~m}$. The data are broken up into three regional types: Sahel desert, mosaic forest, and ocean; and also into two urban areas: Lagos and Niamey. The conurbation of Lagos was estimated to have approximately 17 million residents in 2006, whereas the population of Niamey at that time was slightly under 1 million. South of $10^{\circ} \mathrm{N}$, the surface flow tended to be southwesterly, characteristic of the West African Monsoon, whereas the surface flow became westerly to northwesterly at higher latitudes. Acetone mixing ratios were similar over the Sahel desert and mosaic forest, but were much lower over the ocean (described further in Sect. 4.4). There are enhancements near the urban areas, especially considering that the source air for Lagos is likely from the marine boundary layer, thus initial levels would be quite low. There were no statistically significant differences between acetonitrile mixing ratios in any of the source regions in Table 1. Benzene is lowest over the Sahel, then the ocean, with higher values over the mosaic forest. It is likely 
Table 1. Average mixing ratios ( \pm one standard deviation) measured below GPS altitude of $700 \mathrm{~m}$ over different surface types. The Sahel region encompasses measurements north of $13.8^{\circ} \mathrm{N}$, the mosaic forest between $7.2^{\circ} \mathrm{N}$ and $13.1^{\circ} \mathrm{N}$, and the ocean south of $6.4^{\circ} \mathrm{N}$. Lagos air is selected from a single flight (B229), specifically when the aircraft was downwind of the urban area. Air considered to be influenced by Niamey was encountered shortly after takeoff and before landing on several flights, in the region between 13.1 and $13.8^{\circ} \mathrm{N}$ and between 1.9 and $2.4^{\circ} \mathrm{E}$

\begin{tabular}{lrrrrr}
\hline Compound & Sahel Desert & Mosaic Forest & Ocean & Lagos & Niamey \\
\hline Acetone (ppt) & $1055 \pm 129$ & $1001 \pm 233$ & $485 \pm 178$ & $1128 \pm 564$ & $1183 \pm 259$ \\
Acetonitrile (ppt) & $144 \pm 37$ & $144 \pm 42$ & $133 \pm 38$ & $160 \pm 50$ & $146 \pm 45$ \\
Benzene (ppt) & $25 \pm 35$ & $98 \pm 60$ & $46 \pm 50$ & $264 \pm 244$ & $95 \pm 105$ \\
Isoprene (ppt) & $-9 \pm 47$ & $604 \pm 546$ & $-3 \pm 45$ & $418 \pm 273$ & $67 \pm 114$ \\
MVK+MACR (ppt) & $8 \pm 32$ & $388 \pm 245$ & $2 \pm 47$ & $433 \pm 280$ & $133 \pm 167$ \\
$\mathrm{CO}$ (ppb) & $99 \pm 10$ & $143 \pm 20$ & $119 \pm 13$ & $181 \pm 58$ & $131 \pm 30$ \\
$\mathrm{O}_{3}$ (ppb) & $42 \pm 4$ & $22 \pm 6$ & $27 \pm 5$ & $26 \pm 9$ & $31 \pm 11$ \\
\hline
\end{tabular}
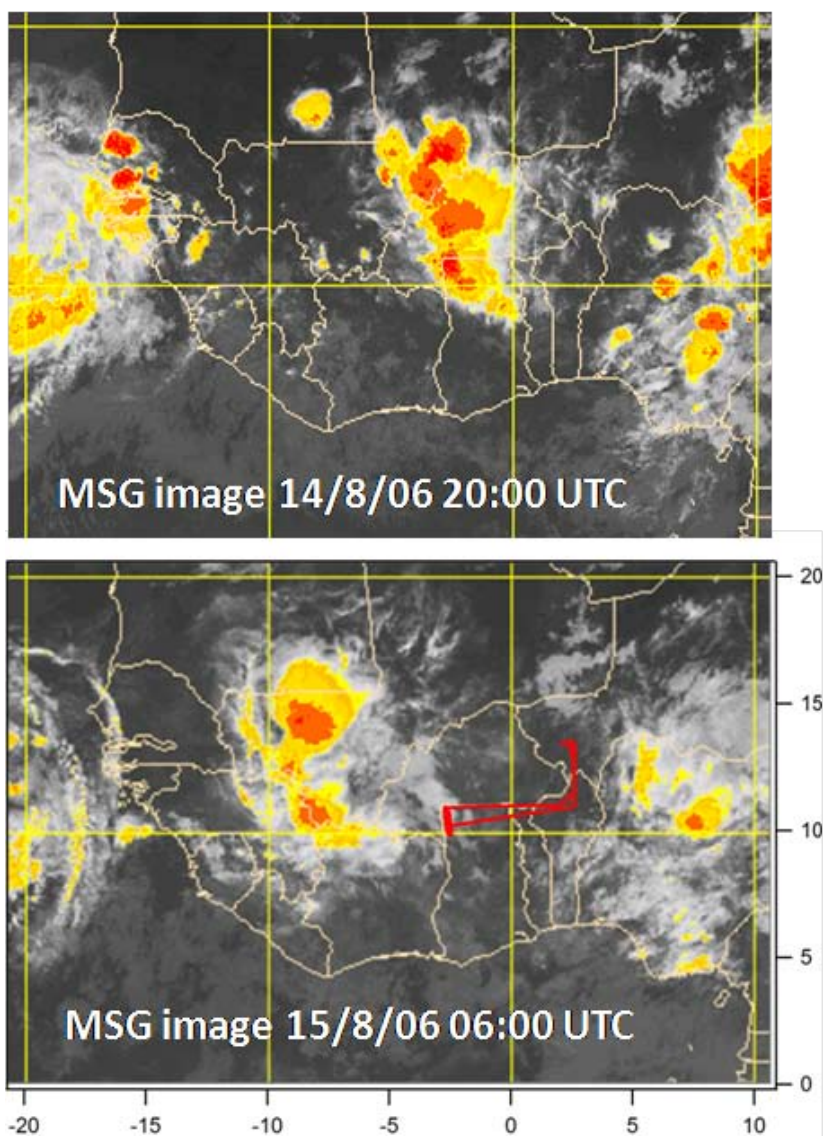

Fig. 3. The MSG satellite image below shows IR brightness temperature (top) when the southern edge of an MCS line associated with the African Easterly Wave crest passed over NW Ghana and (bottom) the cloud deck trailing behind system the following morning, sampled by FAAM (B233 flight track in red).

that benzene emissions from the coastal cities are advected over the forested region contributing to higher values there. The biogenic VOC, isoprene and MVK+MACR, are approximately zero over the Sahel and the ocean, with the highest values over the forest and also enhancements over the urban areas. Northwesterly flow appeared to deliver air with low $\mathrm{CO}$ and high $\mathrm{O}_{3}$, whereas the monsoon flow brought air with higher $\mathrm{CO}$ and lower $\mathrm{O}_{3}$, the latter of which was further depleted by deposition to the forest. The urban areas had enhanced levels of $\mathrm{CO}$, but very little change in the $\mathrm{O}_{3}$. Further descriptions of the geophysical distributions of the trace gases and aerosol can be found in Reeves et al. (2010).

\section{Case studies}

In this section, we focus on four major factors determining the vertical distributions of these VOC in the West African region: (1) deep convective outflow, (2) shallow fair-weather convection, (3) biomass burning outflow, and (4) ocean uptake.

\subsection{Flight in deep convective outflow}

Flight B233 was designed to characterize the outflow of a mesoscale convective system (MCS) over Northern Ghana. Figure 3 shows the Meteosat Second Generation (MSG) images with IR brightness temperature indicating the position and cloudtop altitude of a large mesoscale convective system on (top) 20:00 UTC on 14 Augst 2006 and (bottom) 06:00 UTC on 15 August 2006. The aircraft took off at 04:30 UTC on 15 August to sample air after the passage of the MCS on the previous evening (flight track shown in red on bottom panel of Fig. 3). Between 7000 and 9000 m, there was evidence of convective detrainment layers with thin cloud decks, enhanced $\mathrm{CO}$ and lower $\mathrm{O}_{3}$. After three hours sampling the troposphere at various levels above $5000 \mathrm{~m}$, the aircraft returned to northern Benin and performed a run at minimum altitude to characterize the boundary layer composition. Because this low level run was carried out early in the morning (08:00-08:40), the chemical composition likely reflects that of the residual layer from the previous day's boundary layer. In the hours since the passage of the MCS, this layer would not have been subject to photochemistry 


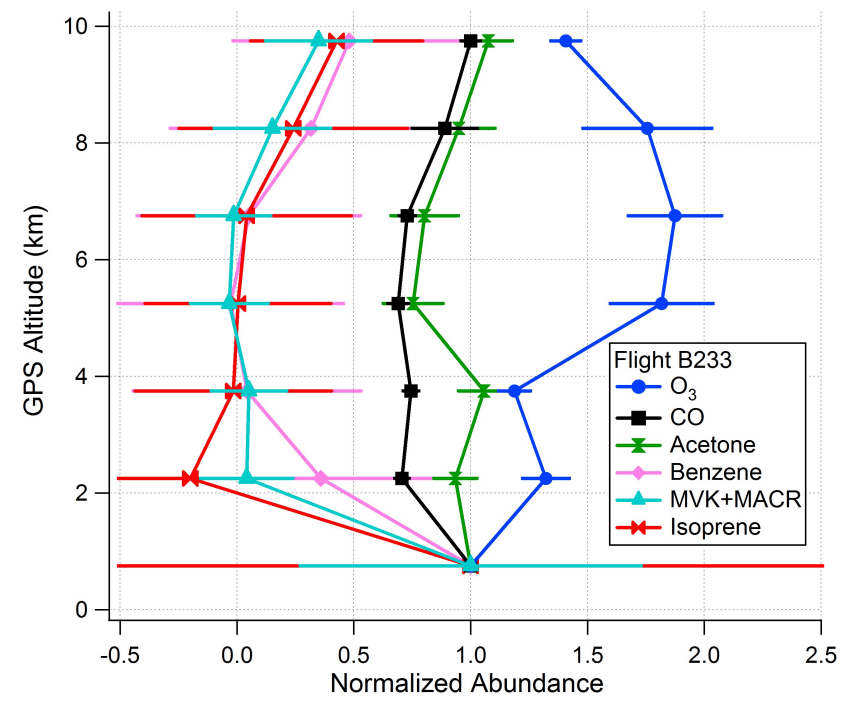

Fig. 4. Normalized altitude profiles of $\mathrm{O}_{3}, \mathrm{CO}$, acetone, benzene, isoprene, and the sum of methyl vinyl ketone and methacrolein from Flight B233. The symbols represent the mean mixing ratio in an altitude bin with a width of $1500 \mathrm{~m}$, normalized to the average mixing ratio in the lowest $1500 \mathrm{~m}$. The error bars represent the standard deviation of the normalized amount.

and would have been dynamically isolated from subsequent emission from and deposition to the surface. Hence we assume that it should be chemically similar to the boundary layer air lofted during the storm passage the previous evening, and we use it to characterize the initial chemical composition of the lofted airmass.

To illustrate the role of deep convection in redistributing chemical species from the boundary layer, Fig. 4 shows the normalized altitude profiles of $\mathrm{CO}, \mathrm{O}_{3}$, acetone, benzene, isoprene, and the sum of methyl vinyl ketone and methacrolein from Flight B233. The symbols represent the mean mixing ratio in an altitude bin with a width of $1500 \mathrm{~m}$, normalized to the average mixing ratio in the lowest $1500 \mathrm{~m}$. $\mathrm{CO}$ and acetone fall off with altitude from the surface, but at layers influenced by convective detrainment, their mixing ratios are close to those observed in the boundary layer. Higher values near $4000 \mathrm{~m}$ may be a result of aged biomass burning plumes, as described in Sect. 4.3. Benzene, isoprene, and MVK+MACR all have much lower background mixing ratios in the mid-troposphere compared with boundary layer values. In the two highest altitude bins, their mixing ratios increase, confirming that boundary layer air has been lofted up to this altitude.

Observations from the French aircraft ATR-42 and Falcon 20 on 19 August show similar C-shaped vertical profiles for VOC, with lowest mixing ratios from $2-6 \mathrm{~km}$, and high values from $6-10 \mathrm{~km}$ (Bechara et al., 2008). The transport of VOC by deep convection is expected to have impacts on the $\mathrm{HO}_{\mathrm{x}}$ and ozone chemistry of the upper troposphere (Collins et al., 1999). Observations from the DLR-Falcon

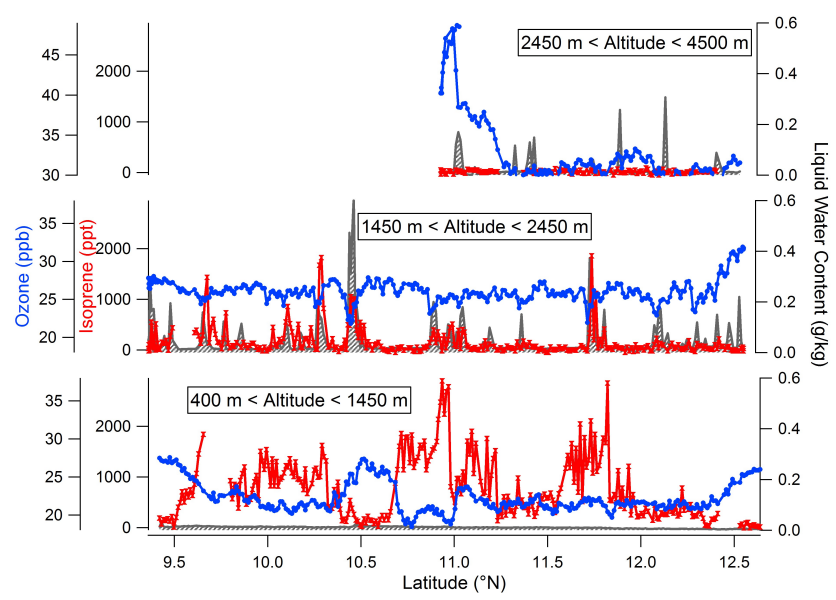

Fig. 5. Observations of ozone, isoprene and liquid water content on Flight B235 during a series of stacked runs at three different levels over a forested area in Benin. Note change in ozone scale in upper panel.

during the same AMMA Special Observing Period show higher values of $\mathrm{HO}_{\mathrm{x}}$ in convective layers when $\mathrm{NO}_{\mathrm{x}}$ is also enhanced (Andres-Hernandez et al., 2009), however ozone in the convective outflow is low. On flight B233, there was no sign of higher nitrogen oxides in the convective outflow sampled. Aircraft sampling of a convective event over Northern France also showed enhancements of acetone, benzene, isoprene, and MVK+MACR, at $11 \mathrm{~km}$ compared to the midtroposphere (Colomb et al., 2006), which were calculated to impact the $\mathrm{HO}_{\mathrm{x}}$ budget dramatically and increase ozone production. Because our observations occur just prior to sunrise, and the air may have been lofted after sunset, it is difficult to use the photochemical lifetimes of the biogenic VOC to constrain the rate of lifting. It is not clear whether the biogenic VOC at this altitude will contribute significantly to ozone production in the upper troposphere. The chemical tendency of ozone in these VOC-enriched airmasses will depend strongly on the abundance of $\mathrm{NO}_{\mathrm{x}}$, which may be influenced by convective lifting of surface emissions or by lightning associated with the MCS. In the case of this flight, no enhancement of $\mathrm{NO}_{\mathrm{x}}$ was observed in the detrainment layers and thus enhancements in photochemical ozone production are not expected. In fact, ozone in these detrainment layers is significantly lower than most upper tropospheric ozone values, due to strong deposition to the forest surface with which it was recently in contact.

\subsection{Flight through cumulus congestus}

Several of the flights focused on characterizing the chemical composition and dynamics of the boundary layer between 9 and $12^{\circ} \mathrm{N}$, in a region of Benin covered by tropical forest with some agricultural activity. Fair weather cumulus congestus cloud was frequently present in the afternoon, 

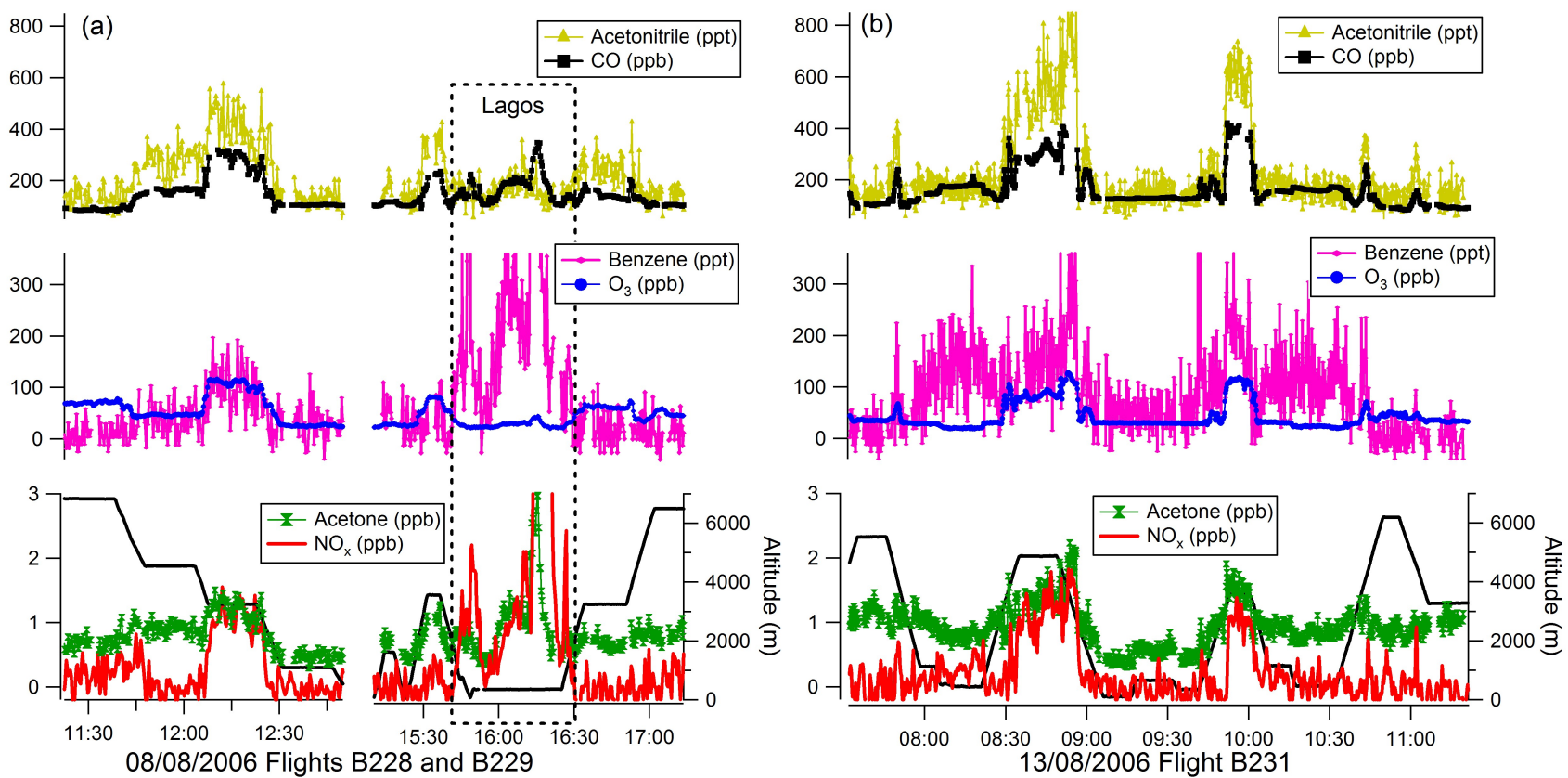

Fig. 6. Time series of flights during which biomass burning outflow was encountered. (a) Flights B228 and B229, both on 8 August 2006. The observations made while the aircraft are sampling air influenced by Lagos (often going off-scale) are outlined in the dotted box. (b) Flight B231 on 13 August 2006.

and runs at the altitude of the cloud layer indicated a strong spatial correspondence between liquid water content and biogenic VOC. This was most dramatic in enhanced isoprene concentrations, but was also apparent in higher MVK+MACR and lower ozone. Flight B235 from $17 \mathrm{Au}-$ gust 2006 provides the most striking example of these observations. An analysis of data from the same flight indicated that surface vegetation heterogeneities led to atmospheric temperature gradients, which controlled the patterns of cumulus congestus cloud formation (Garcia-Carreras et al., 2009).

Figure 5 shows data from three stacked runs during Flight B235 performed at midday over the same vegetated region in Northern Benin. The lower panel illustrates a boundary layer run with high mixing ratios of isoprene and no cloud. The run at the intermediate level shows simultaneous enhancements of liquid water content and isoprene suggesting that the rapid uplift leading to cumulus congestus also contribute to vertical transport of short-lived biogenic species. In the higher run above $2450 \mathrm{~m}$, no isoprene is present in air with cloud, nor are the products MVK+MACR. Ozone shows a strong anti-correlation with isoprene in the boundary layer run and is depleted by several ppb in clouds at the intermediate level. Deposition to vegetation is one of the strong ozone sinks in the region (Saunois et al., 2009), thus high isoprene and low ozone are both indicators that an airmass was in recent contact with the surface. If cloud processing of isoprene oxidation products is a significant source of biogenic secondary organic aerosol (Lim et al., 2005), it may be important to consider this phenomenon, which serves to concentrate isoprene in cloud layers at mixing ratios much higher than their average abundance at that altitude would indicate. There was no indication of enhanced organic aerosol during interception of cloud layers.

\subsection{Flights in biomass burning outflow}

A combination of modelling, in situ and remote sensing observations indicates that enhancements of $\mathrm{O}_{3}$ and $\mathrm{CO}$ in the troposphere over Africa can result from the transport of biomass burning emissions from fires situated in the opposite dry-season hemisphere add (Barret et al., 2008; Mari et al., 2008; Sauvage et al., 2005; Thouret et al., 2009; Real et al., 2010). High acetonitrile observations provided clear evidence of biomass burning outflow during three flights on which the PTR-MS was operated. Figure 6 shows time series of altitude, $\mathrm{O}_{3}, \mathrm{CO}, \mathrm{NO}_{\mathrm{x}}$, acetonitrile, and benzene from three flights: (a) B228 and B229 on 8 August 2006, and (b) flight B231 on 13 August. On 8 August 2006, a high level flight from Niamey to Cotonou encountered biomass burning outflow during stacked runs descending from $6000 \mathrm{~m}$ to $1500 \mathrm{~m}$. After refuelling at Cotonou, the plane passed through these layers again while ascending to $1500 \mathrm{~m}$, then descended to perform a circuit around Lagos (approximately 15:40-16:30) leading to high $\mathrm{NO}_{\mathrm{x}}$ and benzene concentrations. During the ascent back through $6000 \mathrm{~m}$, elevated levels of acetonitrile, $\mathrm{O}_{3}$, and $\mathrm{CO}$, were again observed. In flight B231, the clearest evidence of biomass outflow is seen 
south of $8^{\circ} \mathrm{N}$, between 3000 and $5000 \mathrm{~m}$, though there is evidence for it earlier and later in the flight, whenever the plane ascended or descended around $4000 \mathrm{~m}$. These interceptions occurred over the region between $6^{\circ} \mathrm{N}-11^{\circ} \mathrm{N}$ suggesting the impact of the biomass burning was extensive.

Figure 7a shows a scatter plot of acetonitrile against $\mathrm{CO}$ coloured by the benzene observations for the time periods shown in Fig. 6, but with the observations around Lagos removed. A separate analysis of these flights using whole air samples of VOC found significant emissions of benzene and other aromatics from Lagos (Hopkins et al., 2009). By removing the data with obvious urban influence, we can examine the relative enhancement of acetonitrile compared to $\mathrm{CO}$ in the biomass burning outflow. The line of best fit is overlaid on Fig. 7a and has a slope of $1.69 \pm 0.03 \mathrm{ppt} / \mathrm{ppb}$, within a factor of two with measurements of emission ratios from controlled burning experiments (Christian et al., 2003; Holzinger et al., 1999) and other aircraft observations of biomass burning plumes (Andreae et al., 2001; de Gouw et al., 2003c; Yokelson et al., 2008), though much lower than recent observations in the Yucatan (Yokelson et al., 2009). Figure $7 \mathrm{~b}$ shows a scatterplot of acetonitrile against $\mathrm{CO}$ for the Lagos data on Flight B229, and from the data collected on several flights in the lowest $700 \mathrm{~m}$ in the vicinity of $\mathrm{Ni}$ amey. The slopes for these ratios are much smaller in urban air compared to biomass burning, and the levels of benzene tend to be higher. While no measurements of acetonitrile emissions from urban biofuel burning have been carried out, the low $\mathrm{HCN} / \mathrm{CO}$ emission ratios observed from these fires ( $\sim 0.5 \mathrm{ppt} / \mathrm{ppb}$ ) (Christian et al., 2010) suggest that acetonitrile emissions are likely small. The slopes in Fig. $7 \mathrm{~b}$ $(0.31 \pm 0.08 \mathrm{ppt} / \mathrm{ppb}$ for Lagos and $0.7 \pm 0.1 \mathrm{ppt} / \mathrm{ppb}$ for $\mathrm{Ni}-$ amey) are higher than the value of $0.1 \mathrm{ppt} / \mathrm{ppb}$ observed by de Gouw et al. (2003c) in Los Angeles, but because of the pervasive nature of the biomass burning outflow in the West African region, it is possible that these slopes may not exclusively represent emission ratios for biofuel or other urban combustion.

Acetone was positively correlated with $\mathrm{CO}$ (slope of $3.34 \pm 0.08 \mathrm{ppt} / \mathrm{ppb}$ ) in the plumes with elevated acetonitrile, in contrast to most of the free troposphere where they were anti-correlated. In some aged biomass burning plumes, the ratio of acetone/CO is much larger than the emission ratio as a result of photochemical production of acetone within the plume (e.g. Holzinger et al., 2005; Jost et al., 2003b). However based on the forest fire plumes sampled over North America, de Gouw et al. (2006) did not find clear evidence of secondary production of acetone. The ratios of acetone/CO observed in the AMMA flights are consistent with emission ratios for tropical vegetation measured by Holzinger et al. (1999), Christian et al. (2003), and Jost et al. (2003b), thus it is not clear whether secondary production of acetone has occurred during plume transit.
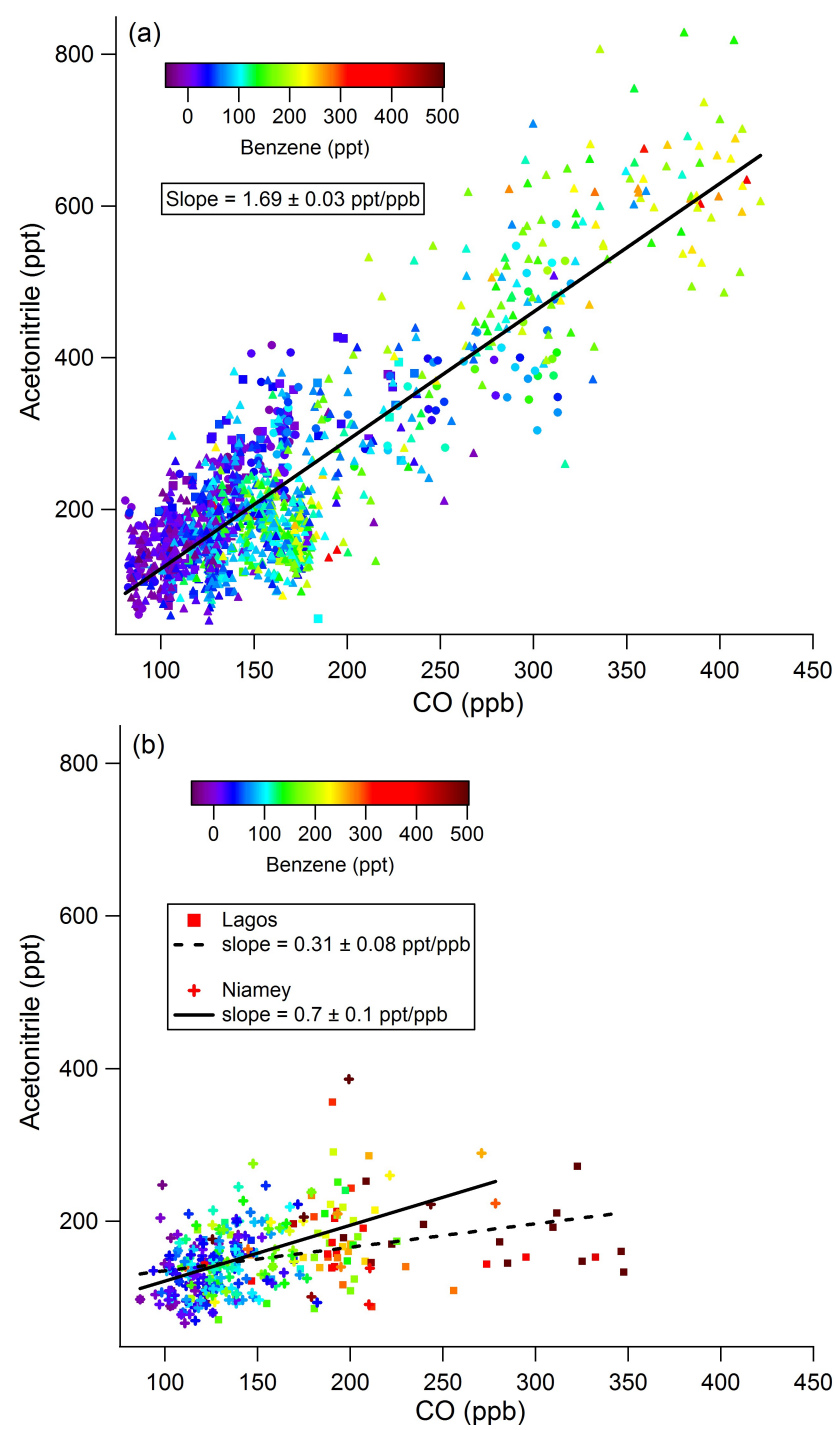

Fig. 7. Scatter plots of acetonitrile against $\mathrm{CO}$ coloured by benzene for (a) all the data from Flight B228 (•), B229 (口) and B231 (4) except the Lagos measurements from B229, and (b) Lagos measurements from B229 and Niamey measurements from several flights.

\subsection{Profiles over the ocean}

Flights B228 and B231 also included profiles over the Gulf of Guinea, between 4 and $6.3^{\circ} \mathrm{N}$. Based on the warm temperatures encountered in the marine boundary layer $(T>292 \mathrm{~K})$, this region does not appear to be an area of significant upwelling. Figure 8 shows altitude profiles of acetone and acetonitrile over the whole campaign with the portions of Flights B228 and B231 south of $6.3^{\circ} \mathrm{N}$ highlighted with black symbols. The predominant flow in the boundary layer at the surface at this time of year is southerly, thus airmasses sampled near the coast may have been over the ocean for days to weeks. It is not clear whether lower acetone values over the Gulf of Guinea indicate an ocean sink, or simply that 

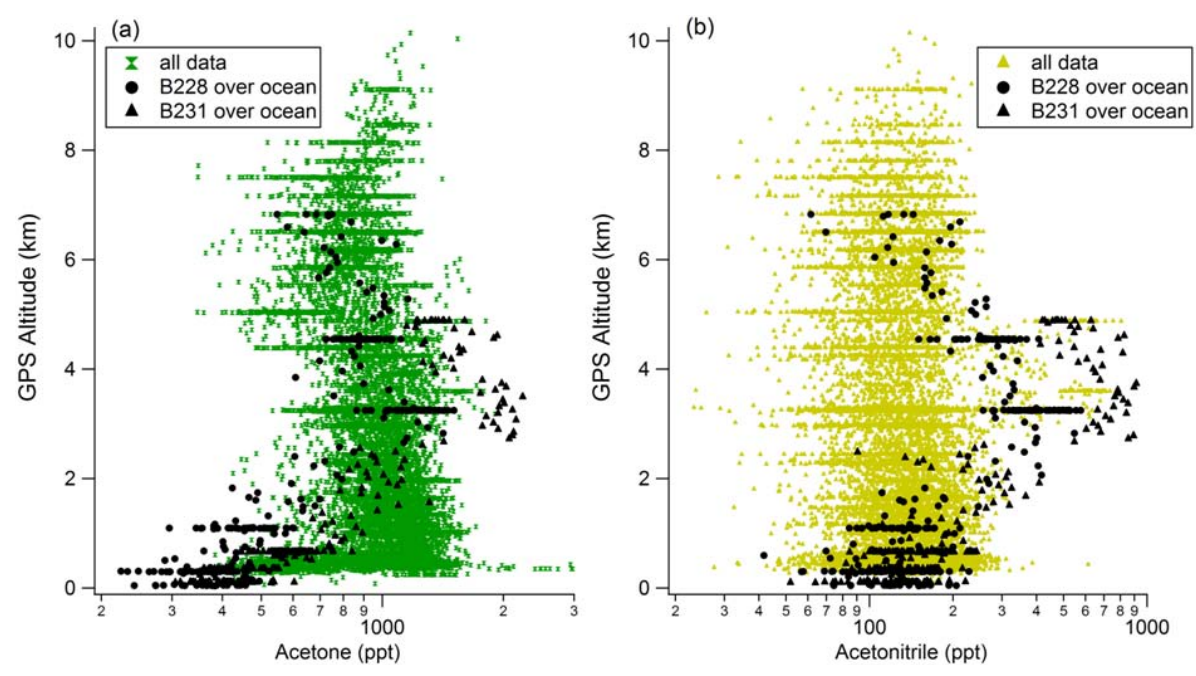

Fig. 8. Vertical profiles of (a) acetone and (b) acetonitrile for all campaign data in coloured symbols and specifically for the data over the Gulf of Guinea, south of $6.3^{\circ} \mathrm{N}$ on Flight B228 (•) and Flight B231 (ム).

terrestrial sources of acetone have not been encountered on a timescale comparable to the lifetime. Shipboard measurements of acetone in the marine boundary layer made slightly further west of this region are similar in magnitude (200$500 \mathrm{ppt}$ ) and in conjunction with surface water concentrations implied highly variable acetone air-sea fluxes (Williams et al., 2004).

The global acetone budget indicates that the ocean can be both a source and a sink of acetone (Jacob et al., 2002), though a more recent evaluation suggests it is a strong net sink globally (Marandino et al., 2005, 2006). Observations demonstrate that the direction of exchange can even change with time of day and other variables at a given location (Sinha et al., 2007) and with biological activity (Taddei et al., 2009). De Reus et al. (2003) compiled acetone measurements from around the world and noted that the slope of acetone vs. $\mathrm{CO}$ was lower in the marine boundary layer $(\sim 14 \mathrm{ppt} / \mathrm{ppb})$ than in the free troposphere $(\sim 23 \mathrm{ppt} / \mathrm{ppb})$ and attributed this difference to ocean uptake in polluted areas and release in pristine environments. On flight B231, the slope of acetone to $\mathrm{CO}$ measured from FAAM in the lowest $1 \mathrm{~km}$ over the ocean was $33 \pm 3 \mathrm{ppt} / \mathrm{ppb}$, and there was a clear decreasing concentration gradient in acetone when approaching the ocean. This suggests that the ocean in this region may be a sink for acetone, despite relatively low ambient mixing ratios. Acetone measurements at a site in Central California were shown to be lower when the airmass was recently over the Pacific, based on back trajectory analysis (Schade and Goldstein, 2006), consistent with an ocean sink, also supported by air-sea flux measurements in the Pacific (Marandino et al., 2005, 2006). Vertical profiles over the tropical Atlantic Ocean during the GABRIEL campaign also show decreasing acetone mixing ratios in the marine boundary layer (Eerdekens et al., 2009).
Loss to the ocean is thought to be one of the main sinks of acetonitrile (Hamm et al., 1984), consistent with lower observations in the marine boundary layer than the free troposphere (de Gouw et al., 2003c; Singh et al., 2003; Karl et al., 2003; Warneke and de Gouw, 2001). While acetonitrile may appear depleted compared to higher altitude observations on flights B228 and B231, this is largely because of the strong enhancements from biomass burning influencing the mid-troposphere. Compared to the overall campaign data, acetonitrile in the marine boundary layer over the Gulf of Guinea does not appear depleted compared to air in the boundary layer or free troposphere over the continent (Table 1). This is in contrast to observations of mixing ratios of less than $30 \mathrm{ppt}$ in the marine boundary layer off the coast of Angola and Namibia in September of 2000 (Jost et al., 2003a). It is possible that a biological sink for acetonitrile, which is not present in the Gulf of Guinea, is required to drive ocean uptake (Bange and Williams, 2000). Along with the measurements of Sanhueza et al. (2004) over the Caribbean Sea, from which they inferred net release of acetonitrile from the ocean, the observations presented in this paper indicate that the ocean cannot always be considered a sink for acetonitrile.

Isoprene and the sum of MVK+MACR were both zero within measurement uncertainty in the marine boundary layer suggesting there are minimal marine biogenic sources of isoprene in the vicinity, consistent with regional estimates provided in Arnold et al. (2009). In mesocosm experiments, Sinha et al. (2007) found that acetone emissions correlated strongly with isoprene emissions, thus low isoprene mixing ratios may indicate the biological sources contributing to acetone emissions are absent in the region. Benzene in the marine boundary layer has no clear vertical gradient and the average mixing ratio was $46 \pm 50 \mathrm{ppt}$, higher than the average 
values in the mid-troposphere. This indicates that these airmasses may have had anthropogenic or biomass burning influence in the last week, arguing more strongly for ocean uptake of acetone.

\section{Summary}

The PTR-MS was used onboard the UK FAAM to make highly time-resolved measurements of select VOC over West Africa during the AMMA campaign in July and August of 2006. During $85 \mathrm{~h}$ of flying time, observations were made that demonstrated that the surface was a source of both biogenic and anthropogenic emissions and also a sink for acetone (ocean) and ozone (forest). Reactive VOC were redistributed to higher altitudes both by shallow convection associated with daytime cumulus congestus, and by deep convection associated with mesoscale convective systems. The highest mixing ratios of benzene were observed in the air over Lagos and Niamey, and in the biomass burning plumes. The highest mixing ratios of acetonitrile were observed in the biomass burning plumes with no clear enhancements in urban air, despite the prevalence of biofuel combustion in Lagos and Niamey. The clearest evidence of biomass burning influence was encountered between 2.5 and $5 \mathrm{~km}$ in altitude. Acetone was higher in the continental boundary layer over the Sahel than over much of the mosaic forest. It was not strongly correlated with $\mathrm{CO}$ in the mid-troposphere and its low abundance in the marine boundary layer implies either ocean uptake or that the sampled airmasses had long residence times over the ocean in the absence of significant sources. Isoprene was confined to the lowest $\sim 1.2 \mathrm{~km}$ above the surface, except on occasions with vigourous convection. Because methyl vinyl ketone and methacrolein are formed as a result of isoprene oxidation, and their photochemical lifetimes are slightly longer, their mixing ratios were not tied as closely to vegetation patterns and they remained at higher abundance to a slightly higher altitude than isoprene.

Acknowledgements. Based on a French initiative, AMMA was built by an international scientific group and is currently funded by a large number of agencies, especially from France, the UK, the US and Africa. This work was funded by the EU and by the UK Natural Environment Research Council through the AMMAUK Consortium grant and the National Centre for Atmospheric Science. The authors thank the anonymous reviewers for their helpful suggestions to improve the manuscript.

Edited by: J. Williams

\section{References}

Aghedo, A. M., Schultz, M. G., and Rast, S.: The influence of African air pollution on regional and global tropospheric ozone, Atmos. Chem. Phys., 7, 1193-1212, doi:10.5194/acp-7-11932007, 2007.

Andreae, M. O., Artaxo, P., Fischer, H., Freitas, S. R., Gregoire, J. M., Hansel, A., Hoor, P., Kormann, R., Krejci, R., Lange, L., Lelieveld, J., Lindinger, W., Longo, K., Peters, W., de Reus, M., Scheeren, B., Dias, M. A. F. S., Strom, J., van Velthoven, P. F. J., and Williams, J.: Transport of biomass burning smoke to the upper troposphere by deep convection in the equatorial region, Geophys. Res. Lett., 28, 951-954, 2001.

Andrés-Hernández, M. D., Kartal, D., Reichert, L., Burrows, J. P., Meyer Arnek, J., Lichtenstern, M., Stock, P., and Schlager, H.: Peroxy radical observations over West Africa during AMMA 2006: photochemical activity in the outflow of convective systems, Atmos. Chem. Phys., 9, 3681-3695, doi:10.5194/acp-9-3681-2009, 2009.

Arnold, S. R., Spracklen, D. V., Williams, J., Yassaa, N., Sciare, J., Bonsang, B., Gros, V., Peeken, I., Lewis, A. C., Alvain, S., and Moulin, C.: Evaluation of the global oceanic isoprene source and its impacts on marine organic carbon aerosol, Atmos. Chem. Phys., 9, 1253-1262, doi:10.5194/acp-9-1253-2009, 2009.

Atkinson, R., Baulch, D. L., Cox, R. A., Crowley, J. N., Hampson, R. F., Hynes, R. G., Jenkin, M. E., Rossi, M. J., Troe, J., and IUPAC Subcommittee: Evaluated kinetic and photochemical data for atmospheric chemistry: Volume II - gas phase reactions of organic species, Atmos. Chem. Phys., 6, 3625-4055, doi:10.5194/acp-6-3625-2006, 2006.

Bange, H. W. and Williams, J.: New Directions: Acetonitrile in atmospheric and biogeochemical cycles, Atmos. Environ., 34, 4959-4960, 2000.

Barret, B., Ricaud, P., Mari, C., Attié, J.-L., Bousserez, N., Josse, B., Le Flochmoën, E., Livesey, N. J., Massart, S., Peuch, V.H., Piacentini, A., Sauvage, B., Thouret, V., and Cammas, J.P.: Transport pathways of $\mathrm{CO}$ in the African upper troposphere during the monsoon season: a study based upon the assimilation of spaceborne observations, Atmos. Chem. Phys., 8, 3231-3246, doi:10.5194/acp-8-3231-2008, 2008.

Bechara, J., Borbon, A., Jambert, C., and Perros, P. E.: New off-line aircraft instrumentation for non-methane hydrocarbon measurements, Anal. Bioanal. Chem., 392, 865-876, 2008.

Capes, G., Murphy, J. G., Reeves, C. E., McQuaid, J. B., Hamilton, J. F., Hopkins, J. R., Crosier, J., Williams, P. I., and Coe, H.: Secondary organic aerosol from biogenic VOCs over West Africa during AMMA, Atmos. Chem. Phys., 9, 3841-3850, doi:10.5194/acp-9-3841-2009, 2009.

Christian, T. J., Kleiss, B., Yokelson, R. J., Holzinger, R., Crutzen, P. J., Hao, W. M., Saharjo, B. H., and Ward, D. E.: Comprehensive laboratory measurements of biomass-burning emissions: 1. Emissions from Indonesian, African, and other fuels, J. Geophys. Res.-Atmos., 108, 4719, doi:10.1029/2003JD003704, 2003.

Christian, T. J., Yokelson, R. J., Cárdenas, B., Molina, L. T., Engling, G., and Hsu, S.-C.: Trace gas and particle emissions from domestic and industrial biofuel use and garbage burning in central Mexico, Atmos. Chem. Phys., 10, 565-584, doi:10.5194/acp-10-565-2010, 2010. 
Collins, W. J., Stevenson, D. S., Johnson, C. E., and Derwent, R. G.: Role of convection in determining the budget of odd hydrogen in the upper troposphere, J. Geophys. Res.-Atmos., 104, 2692726941, 1999.

Colomb, A., Williams, J., Crowley, J., Gros, V., Hofmann, R., Salisbury, G., Klupfel, T., Kormann, R., Stickler, A., Forster, C., and Lelieveld, J.: Airborne measurements of trace organic species in the upper troposphere over Europe: the impact of deep convection, Environ. Chem., 3, 244-259, 2006.

Commane, R., Floquet, C. F. A., Ingham, T., Stone, D., Evans, M. J., and Heard, D. E.: Observations of $\mathrm{OH}$ and $\mathrm{HO}_{2}$ radicals over West Africa, Atmos. Chem. Phys. Discuss., 10, 7265-7322, doi:10.5194/acpd-10-7265-2010, 2010.

Crutzen, P. J. and Andreae, M. O.: Biomass Burning in the Tropics Impact on Atmospheric Chemistry and Biogeochemical Cycles, Science, 250, 1669-1678, 1990.

de Gouw, J., Warneke, C., Karl, T., Eerdekens, G., van der Veen, C., and Fall, R.: Sensitivity and specificity of atmospheric trace gas detection by proton-transfer-reaction mass spectrometry, Int. J. Mass. Spectrom., 223, 365-382, 2003a.

de Gouw, J. A., Goldan, P. D., Warneke, C., Kuster, W. C., Roberts, J. M., Marchewka, M., Bertman, S. B., Pszenny, A. A. P., and Keene, W. C.: Validation of proton transfer reaction-mass spectrometry (PTR-MS) measurements of gas-phase organic compounds in the atmosphere during the New England Air Quality Study (NEAQS) in 2002, J. Geophys. Res.-Atmos., 108, 4682, doi:10.1029/2003JD003863, 2003b.

de Gouw, J. A., Warneke, C., Parrish, D. D., Holloway, J. S., Trainer, M., and Fehsenfeld, F. C.: Emission sources and ocean uptake of acetonitrile $(\mathrm{CH} 3 \mathrm{CN})$ in the atmosphere, J. Geophys. Res.-Atmos., 108, 4329, doi:10.1029/2002JD002897, 2003c.

de Gouw, J. A., Warneke, C., Stohl, A., Wollny, A. G., Brock, C. A., Cooper, O. R., Holloway, J. S., Trainer, M., Fehsenfeld, F. C., Atlas, E. L., Donnelly, S. G., Stroud, V., and Lueb, A.: Volatile organic compounds composition of merged and aged forest fire plumes from Alaska and western Canada, J. Geophys. Res.-Atmos., 111, D10303, doi:10.1029/2005JD006175, 2006.

de Reus, M., Fischer, H., Arnold, F., de Gouw, J., Holzinger, R., Warneke, C., and Williams, J.: On the relationship between acetone and carbon monoxide in different air masses, Atmos. Chem. Phys., 3, 1709-1723, doi:10.5194/acp-3-1709-2003, 2003.

Eerdekens, G., Ganzeveld, L., Vilà-Guerau de Arellano, J., Klüpfel, T., Sinha, V., Yassaa, N., Williams, J., Harder, H., Kubistin, D., Martinez, M., and Lelieveld, J.: Flux estimates of isoprene, methanol and acetone from airborne PTR-MS measurements over the tropical rainforest during the GABRIEL 2005 campaign, Atmos. Chem. Phys., 9, 4207-4227, doi:10.5194/acp-9-42072009, 2009.

Ferreira, J., Reeves, C. E., Murphy, J. G., Garcia-Carreras, L., Parker, D. J., and Oram, D. E.: Isoprene emissions modelling for West Africa using MEGAN, Atmos. Chem. Phys. Discuss., 10, 6923-6953, doi:10.5194/acpd-10-6923-2010, 2010.

Garcia-Carreras, L., Parker, D. J., Taylor, C. M., Reeves, C. E., and Murphy, J. G.: The impact of mesoscale vegetation heterogeneities on the dynamical and thermodynamic properties of the planetary boundary layer, J. Geophys. Res.-Atmos., 115, D03102, doi:10.1029/2009JD012811, 2010.
Guenther, A., Karl, T., Harley, P., Wiedinmyer, C., Palmer, P. I., and Geron, C.: Estimates of global terrestrial isoprene emissions using MEGAN (Model of Emissions of Gases and Aerosols from Nature), Atmos. Chem. Phys., 6, 3181-3210, doi:10.5194/acp-63181-2006, 2006.

Hamm, S., Hahn, J., Helas, G., and Warneck, P.: Acetonitrile in the Troposphere - Residence Time Due to Rainout and Uptake by the Ocean, Geophys. Res. Lett., 11, 1207-1210, 1984.

Holzinger, R., Warneke, C., Hansel, A., Jordan, A., Lindinger, W., Scharffe, D. H., Schade, G., and Crutzen, P. J.: Biomass burning as a source of formaldehyde, acetaldehyde, methanol, acetone, acetonitrile, and hydrogen cyanide, Geophys. Res. Lett., 26, 1161-1164, 1999.

Holzinger, R., Williams, J., Salisbury, G., Klüpfel, T., de Reus, M., Traub, M., Crutzen, P. J., and Lelieveld, J.: Oxygenated compounds in aged biomass burning plumes over the Eastern Mediterranean: evidence for strong secondary production of methanol and acetone, Atmos. Chem. Phys., 5, 39-46, doi:10.5194/acp-5-39-2005, 2005.

Hopkins, J. R., Lewis, A. C., and Read, K. A.: A two-column method for long-term monitoring of non-methane hydrocarbons (NMHCs) and oxygenated volatile organic compounds (oVOCs), J. Environ. Monitor., 5, 8-13, 2003.

Hopkins, J. R., Evans, M. J., Lee, J. D., Lewis, A. C., H Marsham, J., McQuaid, J. B., Parker, D. J., Stewart, D. J., Reeves, C. E., and Purvis, R. M.: Direct estimates of emissions from the megacity of Lagos, Atmos. Chem. Phys., 9, 8471-8477, doi:10.5194/acp9-8471-2009, 2009.

Jacob, D. J., Field, B. D., Jin, E. M., Bey, I., Li, Q. B., Logan, J. A., Yantosca, R. M., and Singh, H. B.: Atmospheric budget of acetone, J. Geophys. Res.-Atmos., 107, 4100, doi:10.1029/2001JD000694, 2002.

Janicot, S., Thorncroft, C. D., Ali, A., Asencio, N., Berry, G., Bock, O., Bourles, B., Caniaux, G., Chauvin, F., Deme, A., Kergoat, L., Lafore, J.-P., Lavaysse, C., Lebel, T., Marticorena, B., Mounier, F., Nedelec, P., Redelsperger, J.-L., Ravegnani, F., Reeves, C. E., Roca, R., de Rosnay, P., Schlager, H., Sultan, B., Tomasini, M., Ulanovsky, A., and ACMAD forecasters team: Large-scale overview of the summer monsoon over West Africa during the AMMA field experiment in 2006, Ann. Geophys., 26, 25692595, 2008, http://www.ann-geophys.net/26/2569/2008/.

Jost, C., Trentmann, J., Sprung, D., Andreae, M. O., and Dewey, K.: Deposition of acetonitrile to the Atlantic Ocean off Namibia and Angola and its implications for the atmospheric budget of acetonitrile, Geophys. Res. Lett., 30, 1837, doi:10.1029/2003GL017347, 2003a.

Jost, C., Trentmann, J., Sprung, D., Andreae, M. O., McQuaid, J. B., and Barjat, H.: Trace gas chemistry in a young biomass burning plume over Namibia: Observations and model simulations, J. Geophys. Res.-Atmos., 108, 8482, doi:10.1029/2002JD002431, 2003b.

Karl, T., Hansel, A., Mark, T., Lindinger, W., and Hoffmann, D.: Trace gas monitoring at the Mauna Loa Baseline observatory using proton-transfer reaction mass spectrometry, Int. J. Mass. Spectrom., 223, 527-538, 2003. 
Lee, A., Schade, G. W., Holzinger, R., and Goldstein, A. H.: A comparison of new measurements of total monoterpene flux with improved measurements of speciated monoterpene flux, Atmos. Chem. Phys., 5, 505-513, doi:10.5194/acp-5-505-2005, 2005.

Lim, H. J., Carlton, A. G., and Turpin, B. J.: Isoprene forms secondary organic aerosol through cloud processing: Model simulations, Environ. Sci. Technol., 39, 4441-4446, 2005.

Lindinger, W., Hansel, A., and Jordan, A.: On-line monitoring of volatile organic compounds at pptv levels by means of protontransfer-reaction mass spectrometry (PTR-MS) - Medical applications, food control and environmental research, Int. J. Mass. Spectrom., 173, 191-241, 1998.

Marandino, C. A., De Bruyn, W. J., Miller, S. D., Prather, M. J., and Saltzman, E. S.: Oceanic uptake and the global atmospheric acetone budget, Geophys. Res. Lett., 32, L15806, doi:10.1029/2005GL023285, 2005.

Marandino, C. A., De Bruyn, W. J., Miller, S. D., Prather, M. J., and Saltzman, E. S.: Correction to "Oceanic uptake and the global atmospheric acetone budget”, Geophys. Res. Lett., 33, L24801, doi:10.1029/2006GL028225, 2006.

Mari, C. H., Cailley, G., Corre, L., Saunois, M., Attié, J. L., Thouret, V., and Stohl, A.: Tracing biomass burning plumes from the Southern Hemisphere during the AMMA 2006 wet season experiment, Atmos. Chem. Phys., 8, 3951-3961, doi:10.5194/acp-8-3951-2008, 2008.

Murphy, J. G., Oram, D. E., Reeves, C. E., Lee, J. D., Hopkins, J. R., Taylor, C. M., McQuaid, J. B., and Parker, D. J.: Observations of Isoprene and Its Oxidation Products Over West Africa, EOS Trans AGU Fall Meeting, 2006.

Northway, M. J., de Gouw, J. A., Fahey, D. W., Gao, R. S., Warneke, C., Roberts, J. M., and Flocke, F.: Evaluation of the role of heterogeneous oxidation of alkenes in the detection of atmospheric acetaldehyde, Atmos. Environ., 38, 6017-6028, 2004.

Pfister, G. G., Emmons, L. K., Hess, P. G., Lamarque, J. F., Orlando, J. J., Walters, S., Guenther, A., Palmer, P. I., and Lawrence, P. J.: Contribution of isoprene to chemical budgets: A model tracer study with the NCAR CTM MOZART-4, J. Geophys. Res.-Atmos., 113, D05308, doi:10.1029/2007JD008948, 2008.

Real, E., Orlandi, E., Law, K. S., Fierli, F., Josset, D., Cairo, F., Schlager, H., Borrmann, S., Kunkel, D., Volk, C. M., McQuaid, J. B., Stewart, D. J., Lee, J., Lewis, A. C., Hopkins, J. R., Ravegnani, F., Ulanovski, A., and Liousse, C.: Cross-hemispheric transport of central African biomass burning pollutants: implications for downwind ozone production, Atmos. Chem. Phys., 10, 3027-3046, doi:10.5194/acp-10-3027-2010, 2010.

Reeves, C. E., Formenti, P., Afif, C., Ancellet, G., Attie, J.-L., Bechara, J., Borbon, A., Cairo, F., Coe, H., Crumeyrolle, S., Fierli, F., Flamant, C., Gomes, L., Hamburger, T., Lambert, C., Law, K. S., Mari, C., Matsuki, A., Methven, J., Mills, G. P., Minikin, A., Murphy, J. G., Nielsen, J. K., Oram, D. E., Parker, D. J., Richter, A., Schlager, H., Schwarzenboeck, A., and Thouret, V.: Chemical and aerosol characterisation of the troposphere over West Africa during the monsoon period as part of AMMA, Atmos. Chem. Phys. Discuss., 10, 7115-7183, doi:10.5194/acpd-10-7115-2010, 2010.
Sanhueza, E., Holzinger, R., Kleiss, B., Donoso, L., and Crutzen, P. J.: New insights in the global cycle of acetonitrile: release from theocean and dry deposition in the tropical savanna of Venezuela, Atmos. Chem. Phys., 4, 275-280, doi:10.5194/acp-4-275-2004, 2004.

Saunois, M., Reeves, C. E., Mari, C. H., Murphy, J. G., Stewart, D. J., Mills, G. P., Oram, D. E., and Purvis, R. M.: Factors controlling the distribution of ozone in the West African lower troposphere during the AMMA (African Monsoon Multidisciplinary Analysis) wet season campaign, Atmos. Chem. Phys., 9, 61356155, doi:10.5194/acp-9-6135-2009, 2009.

Sauvage, B., Thouret, V., Cammas, J.-P., Gheusi, F., Athier, G., and Nëdélec, P.: Tropospheric ozone over Equatorial Africa: regional aspects from the MOZAIC data, Atmos. Chem. Phys., 5, 311335, doi:10.5194/acp-5-311-2005, 2005.

Saxton, J. E., Lewis, A. C., Kettlewell, J. H., Ozel, M. Z., Gogus, F., Boni, Y., Korogone, S. O. U., and Serça, D.: Isoprene and monoterpene measurements in a secondary forest in northern Benin, Atmos. Chem. Phys., 7, 4095-4106, doi:10.5194/acp-74095-2007, 2007.

Schade, G. W. and Goldstein, A. H.: Seasonal measurements of acetone and methanol: Abundances and implications for atmospheric budgets, Global Biogeochem. Cy., 20, GB1011, doi:10.1029/2005GB002566, 2006.

Singh, H. B., Salas, L., Herlth, D., Kolyer, R., Czech, E., Viezee, W., Li, Q., Jacob, D. J., Blake, D., Sachse, G., Harward, C. N., Fuelberg, H., Kiley, C. M., Zhao, Y., and Kondo, Y.: In situ measurements of $\mathrm{HCN}$ and $\mathrm{CH}_{3} \mathrm{CN}$ over the Pacific Ocean: Sources, sinks, and budgets, J. Geophys. Res.-Atmos., 108, 8795, doi:10.1029/2002JD003006, 2003.

Sinha, V., Williams, J., Meyerhöfer, M., Riebesell, U., Paulino, A. I., and Larsen, A.: Air-sea fluxes of methanol, acetone, acetaldehyde, isoprene and DMS from a Norwegian fjord following a phytoplankton bloom in a mesocosm experiment, Atmos. Chem. Phys., 7, 739-755, doi:10.5194/acp-7-739-2007, 2007.

Stavrakou, T., Müller, J.-F., De Smedt, I., Van Roozendael, M., Kanakidou, M., Vrekoussis, M., Wittrock, F., Richter, A., and Burrows, J. P.: The continental source of glyoxal estimated by the synergistic use of spaceborne measurements and inverse modelling, Atmos. Chem. Phys., 9, 8431-8446, doi:10.5194/acp-9-8431-2009, 2009.

Taddei, S., Toscano, P., Gioli, B., Matese, A., Miglietta, F., Vaccari, F. P., Zaldei, A., Custer, T., and Williams, J.: Carbon Dioxide and Acetone Air-Sea Fluxes over the Southern Atlantic, Environ. Sci. Technol., 43, 5218-5222, 2009.

Thouret, V., Saunois, M., Minga, A., Mariscal, A., Sauvage, B., Solete, A., Agbangla, D., Nédélec, P., Mari, C., Reeves, C. E., and Schlager, H.: An overview of two years of ozone radio soundings over Cotonou as part of AMMA, Atmos. Chem. Phys., 9, 6157-6174, doi:10.5194/acp-9-6157-2009, 2009.

Vrekoussis, M., Wittrock, F., Richter, A., and Burrows, J. P.: Temporal and spatial variability of glyoxal as observed from space, Atmos. Chem. Phys., 9, 4485-4504, doi:10.5194/acp-9-44852009, 2009. 
Warneke, C. and de Gouw, J. A.: Organic trace gas composition of the marine boundary layer over the northwest Indian Ocean in April 2000, Atmos. Environ., 35, 5923-5933, 2001.

Warneke, C., de Gouw, J. A., Kuster, W. C., Goldan, P. D., and Fall, R.: Validation of atmospheric VOC measurements by proton-transfer-reaction mass spectrometry using a gaschromatographic preseparation method, Environ. Sci. Technol., 37, 2494-2501, 2003.

Williams, J., Holzinger, R., Gros, V., Xu, X., Atlas, E., and Wallace, D. W. R.: Measurements of organic species in air and seawater from the tropical Atlantic, Geophys. Res. Lett., 31, L23S06, doi:10.1029/2004GL020012, 2004.

Williams, J. E., Scheele, M. P., van Velthoven, P. F. J., Cammas, J.-P., Thouret, V., Galy-Lacaux, C., and Volz-Thomas, A.: The influence of biogenic emissions from Africa on tropical tropospheric ozone during 2006: a global modeling study, Atmos. Chem. Phys., 9, 5729-5749, doi:10.5194/acp-9-5729-2009, 2009.
Yokelson, R. J., Christian, T. J., Karl, T. G., and Guenther, A.: The tropical forest and fire emissions experiment: laboratory fire measurements and synthesis of campaign data, Atmos. Chem. Phys., 8, 3509-3527, doi:10.5194/acp-8-3509-2008, 2008.

Yokelson, R. J., Crounse, J. D., DeCarlo, P. F., Karl, T., Urbanski, S., Atlas, E., Campos, T., Shinozuka, Y., Kapustin, V., Clarke, A. D., Weinheimer, A., Knapp, D. J., Montzka, D. D., Holloway, J., Weibring, P., Flocke, F., Zheng, W., Toohey, D., Wennberg, P. O., Wiedinmyer, C., Mauldin, L., Fried, A., Richter, D., Walega, J., Jimenez, J. L., Adachi, K., Buseck, P. R., Hall, S. R., and Shetter, R.: Emissions from biomass burning in the Yucatan, Atmos. Chem. Phys., 9, 5785-5812, doi:10.5194/acp-9-5785-2009, 2009. 